\title{
ITINERANT FIGURES
}

\section{Textual Mobilities in Fiction's Diasporic Turn}

\author{
Maria Luisa Torres Reyes \\ Ateneo de Manila University and the University of Santo Tomas \\ lu2reyes2x@gmail.com
}

Diasporas are dynamic and volatile in today's globalizing realities and imaginaries because the sense of place and location by which diasporic experiences are understood has become fluid, ambiguous, even contested, and no longer a fixed and static space. ${ }^{1}$ In the case of Filipinos in the United States or Koreans or Chinese in Japan, for example, and the history of colonial relations that now bind or separate them, diaspora is a process that has taken place in the gap between them as former colonizer and colonized. In the process of globalization fractured at the very site of identification of the postcolonial self, it becomes that liminal space in-between, constituting, at once, demand and desire. ${ }^{2}$

In the fictional texts analyzed in this special forum written either during or after direct colonial rule, an access is given to fleeting transnational images of the fugitive and ephemeral displacement, dispersal and migrancy of intellectuals and ordinary people that underscore cultural difference in their diasporic experience. However complex that access might be in view of the diverse and multi-layered methodological protocols of interpretive reading, we find diasporic subjects that are present but invisible in a foreign land, mobile but constrained, located but displaced, connected yet isolated, real but illusory. In other words, we see shadows of metaphorically liminal sites of possession and loss, participation and alienation, subjectivity and subjection.

Given the transnational character of diasporas marked by fissures, what "transnationality" 3 is created and invented or torn apart and nipped in the bud in the fictional selves of the protagonists and the communities?

Dae-geun Lim and Donghyun Kim's article, "A Portrait of a Modern Chinese Youth in Diaspora: Re-reading Yu Da-fu's Novels" analyzes two works of Yu $\mathrm{Da}-\mathrm{Fu}$, a modern Chinese short story writer and poet, which narrate the diasporic experience of young Chinese intellectuals who were caught in a difficult period of transition to modernization while living in Imperial Japan as students. In Yu Da-fu's 
fiction, the characters are cast into the Japanese society in which they face personal existential problems in the development of the modern self-an experience that might be said to be symbolic of a kind of modern anomie involving a confrontation between the "I" and the world. ${ }^{4}$

Such problems are depicted in the characters' social relationships concerning money, fame, sexual issues, and others in his debut piece Silver-Gray Death (1921) and representative work Sinking (1921). On one level, it may be said that the anomic "I" or "He" represented in these works is rooted in the experience of personal recontextualization characterized by adjustment problems in the modernizing Japanese society, experiencing despair. On another level, these works help explain why the experience of the modern Chinese youth in diaspora failed to completely form a modern "self."

The paper examines how the self, a constructed entity, is shaped by modern forces such as the experience of diaspora. Through the novel's formal composition, the complex interface between migration and the development of personal identity is analyzed in view of the impact of such forces upon the constitution or reconstitution of the self. Re-contextualized from traditional China to modernizing Japan, the walls that divide cultures are deemed impenetrable, and the modern self struggles to emerge fully and merge with the world. If diasporic migrancy is about adaptation and construction, then failure in one results in the failure in another. Unable to adapt to dislocations and transformations in Japan, the Chinese protagonist becomes unable to construct new forms of knowledge between the world and the self.

Inseop Shin's article, "A Narrative of Those on the Move, The West as a Mirror and the Complex of Modern Japanese Literature: The Case of Takeo Arishima," analyzes A Certain Woman (1919), a novel about a Japanese woman who is compelled to emigrate to America but does not complete her voyage. Yoko, the heroine, wears Western clothes and copies Western trends, reflecting her admiration for the West. But her failure suggests an instability in her self-identity as the novel deploys the motif of the vagabond which is fairly rare in Japanese literature.

Working against the grain of dominant national narratives during its time which often depicted the self-satisfaction of the Japanese within Japan, this novel portrays a main character's desire to leave and live elsewhere. In addition, unlike its mainstream contemporary works which focused on Japan's racial singularity within the territory of Japan, A Certain Woman deals with the themes of diaspora and Orientalism. The novel, as the paper points out, engages with highly political and multi-layered themes concerning Eastern attitudes towards the West, setting the reader up for a dynamic engagement with the novel's diasporic textuality.

Kritika Kultura 28 (2017): -197 
In the narrative, as the body moves through space, it crosses over geographical divides but stops short of traversing metaphorical borders, the kind that really matters in the novel. Caught between the nation and its Other, the self is confronted with the intimations of diaspora across the seas from point of origin to point of destination. In transit, the movement of migrancy provides a spatial vehicle to locate the fragile identity of the self-Othering self in its mimicry of the Other, reflecting the location through which the character has moved-that vast but uncertain stretch of waters between Japan and America. ${ }^{5}$

Jooyoung Kim's article, “The Diaspora of an Empire: The Identity of a Young Intellectual of Colonial Korea: Focusing on Into the Light by Sa-ryang Kim,"6 examines Into the Light (1939), a Korean novel set during the Japanese colonial times, written by a Korean author in the Japanese language about the psychological split suffered by a young intellectual who settles in Japan after drifting away from his homeland. The protagonist, who adopts a Japanese surname and enrolls in a most prestigious college, attempts to imitate the other intellectuals among the Japanese elite in his search for identity. However, as he encounters the other characters, what he discovers is the Korean in him, mirroring no one but his Korean self. Thus, his original Korean name and his adopted Japanese name begin to conflict with one another, splitting his identity apart.

Moreover, a triangular relationship is created between the protagonist and two other characters mirroring the similarities and differences between them, thereby engendering a fluid analysis of the text. Haruo, one of the characters who has an interracial identity from both his Korean and Japanese bloodlines, undergoes a clash between his desired Japanese self and the unmistakable traces of his Korean ancestry. Meanwhile, the other character, Lee, keeps true to his Korean roots and refuses to imitate the Japanese. This novel, whose narrative weaves together the story of these three characters, portrays the conflicts in the identity of the colonized people, producing irrationalities, heterogeneities, denials and conflicts within the self particularly of the colonial intellectual.

Explored in the analysis of the novel is the multiplicity and contradictions of diasporic experiences and relations in that complex colonial transnational space between Korea and Japan, animating their material and metaphorical significance. Imagined geographies between the country of origin and the country of settlement transform diasporic identities in the hope of constructing one's home beyond the homeland. In the midst of successes, failures, resistance, endurance, identities either reveal fractured psyches of apparently static selves or unveil discrepant or contradictory mobile modernities, and all the problems and potentialities between. 
Ma. Socorro Q. Perez's article, "White Citizenship: A Category of Identification and Route of US Immigrant Constitution," asserts that the contours of diasporic identity and consciousness is not just limited to the oscillation of subjects in transnational spaces and multiplicity of cultures but is formed and impelled by US hegemonic norms, racialized immigration laws and policies, and the discourse of "white ideal," enabling an immigrant positioning that is dialectically complex. ${ }^{7}$ The rendering of this particular diasporic formulation is in the deployment of historical and materialist optics. For example, the study of the history of Asian American struggle for US naturalization and its shifts is crucial in fully understanding the contours of Asian American diaspora, of which Filipino/Ilocano Hawaiian/ American diaspora is constituted, and their corresponding contestation and appeal of ethnicity as a category vis-a-vis the poles of White/Black binary as the only legitimate yardstick in the bid for US citizenship.

Narrative forms, like the novel or short fiction are powerful sites for "mirroring" the experience of diaspora in a reciprocally constitutive process. For example, as the ultimate goal of the Filipino/Ilocano-Hawaiian immigrants is in obtaining the badge of national belonging through the US citizenship, the grand narrative produced is in their replication of the discourse of white ideal. However, the realities, racializing, US hegemonic discourses, and their dehistoricizing logic impel the immigrants to pursue group-determination endeavors and views, which may run counter to the regulatory norms. The ambivalence of white discourse opens it up to distortion or refraction, allowing room for the emergence of the marginal-in this case, the representation of Ilocano-Hawaiian ethnic minority, as embodied in GUMIL Hawaii diasporic literature.

The diasporic fiction of the writers of GUMIL Hawaii shows how new identities and homes are constructed in the migrants' new homelands shaped as much by the "culture of citizenship" or civic participation as by the constraints of regulatory policies. The originary place becomes an imaginary trajectory of various creative possibilities opened up locally and internationally by the activities of diasporas-as much for the Ilocos region in the Philippines as for Hawaii of the US. Impelled by the desire to be "white," and struggles over the social regulation of the sense of belonging, the complexities of citizenship are negotiated in attempts to locate alternative spaces for mobilization. Through their short stories, identities are "performed," reconstructed and reinvented through a variety of active diasporic interventions which are shown to constitute diasporic political engagements in themselves as a response to the racializing discourse of US hegemony.

It is noteworthy that in the critical trajectories of these papers, the metaphor of the mirror which embodies the re-presentation of diaspora and migrancy is recurrent. Indeed, fiction, in general, or the postcolonial novel, in particular, is

Kritika Kultura 28 (2017): -197 
associated with the notion of realistic representation in which "reality" seeks reflection in the postcolonial mirror.

As a critical concept, literary realism of the nineteenth century in the West, for example, has been said to be capable of re-presenting something "real" although the connection between the thing and the representation of the thing has been problematized for some time now. In The Red and the Black, Stendhal is often cited for comparing the realist novel with "a mirror carried along a roadway," for which passage he has also been criticized for its "epistemological naivete." In East Asia of the 1920 and the 1930s, in fact, the influence of Western literary realism was at its peak. The same literary historical development was evident in the rest of Asia, in a number of ways, including the Philippines.

As "mirror," fictional representation does not necessarily "mirror." The images produced might appear clear or blurred like shadows by way of a reflection, refraction, deflection, images of dystopic nightmare or utopian vision. ${ }^{8}$ Diaspora, with its unique sense of being alienated but situated, and in its implied sense of paradoxical and contradictory kind of real and metaphorical mobility, produces far more challenging portrayals, and narratives. In diasporic fiction, descriptive images and narrative lines are in constant motion, materially and symbolically, in which the self may not be clearly visible, even to oneself.

The fictional geographies of diaspora explored in these papers help identify certain textual strategies and contextual wellsprings of diasporic literature in an attempt at an open and fluid interpretive literary and critical understanding of diaspora's inscription in the material and imagined world. In this diasporic world, "homeland" has become a complex space to stake a claim-a nostalgic point of departure and return for some, but also a site of personal and political struggles for others-about what is inside or outside, included or excluded, the Self or the Other.

In the recent global diasporic turn in literary and cultural studies, to engage with this complexity is to stake a claim to the only planet that is home to all. 


\section{Notes}

1. Part of diaspora's volatility owes to a contingency of considerations including the "situation and status of migrants." As Fouron explains: "These dispersals may take the form of modern diasporas, incipient diasporas, stateless diasporas, statebased diasporas or dormant diasporas. Although distinctive in important ways, these various types of diasporas also share common characteristics" (Fouron 461).

2. Following Homi Bhabha in The Location of Culture, from the site of liminality emerges the interstices of intersubjective negotiation across differences of "national identity," a kind of interstitial transit in which the apparently stable subject breaks up into a multiplicity of identifications (5).

3. For Bhabha, hybrid formations are disruptive of established identities: "The representation of difference must not be hastily read as the reflection of pre-given ethnic or cultural traits set in the fixed tablet of tradition. The social articulation of difference, from the minority perspective, is a complex, on-going negotiation that seeks to authorize cultural hybridities that emerge in moments of historical transformation" (2).

4. "Sinking," a famous story by Yu Da-fu, for example, is said to be one of "the first psychological stories in the history of modern Chinese fiction and its significance in Chinese literary history is said to lie in its radically new focus on the personal, the profoundly subjective... The mind through which the story unfolds is, moreover, a modern mind, alienated from society, turned in on itself, an ultimately divided" (Denton 107).

5. Self-Orientalism has been said to be the flip-side of Orientalism, as much an invention of the West as of the Orient. In "Chinese History and the Question of Orientalism," Dirlik argues that:

Said's Orientalism, as he is quick to acknowledge, is a study in EuroAmericanthought, and it has little to say on the question of how intellectuals and others in Asian societies may have contributed to the emergence of orientalism aspractice and concept. And even if orientalism was a product of a European intellectual space, how did "oriental" intellectuals respond to it, or receive it? Were the "orientals" indeed as silent, or incapable of representing themselves, as Said's study suggests? How does "orientalism" and the whole question of a modern consciousness appear when we bring the "orientals" into the picture, not as silent objects of a European discourse, but as active participants in its emergence? What bearing would such a reconstructed picture of orientalism have on the question of the relationship between orientalism and power? While Said is quite right in arguing that orientalism derives from an inside/outside (or occident/orient) distinction, moreover, is it possible that in the long run the consequence of orientalism is to call such a distinction into question? (101)

6. An abstract in a conference explains the positive reception to the works of Kim Saryang in Japan in the 1970s:

Kritika Kultura 28 (2017): -197

(C) Ateneo de Manila University

<http://journals.ateneo.edu/ojs/kk/> 
The reasons why Kim Saryang's literature was given such a high re-assessment in the Japanese society around the 1970s, are not limited to the fact that it was written in Japanese in the end of Imperial Japan's era. It was also highly appraised because of its inherent anti-imperialist internationalism. Kim Saryang was again in demand in Japan at the point when post-war Japan needed critical reflection on its past. It demonstrates that Kim Saryang's literature had a pan-regional, East Asian quality, rather than being simply definable as "national" or "ethno-national" literature. (Hyoungduck Kwak)

7. Historically, Filipino Americans have suffered from various forms of discrimination involving immigration and naturalization, citizenship and treatment of Filipino Americans (Ancheta 93).

8. The metaphor of the mirror is a recurrent figure in postcolonial discourse in relation to the concepts of the Other, the process of othering and mimicry. Parashkevova asserts that "[t]hese concepts refer to those aspects of the mirror as a cultural phenomenon that concern the formation of subjectivity, particularly colonial subjectivity, and the relationship between the original and the mirror image-here, the ambivalent relationship between the colonizer and colonized" (18). 


\section{Works Cited}

Ancheta, Angelo N. "Filipino Americans, Foreigner Discrimination, and the Lines of Racial Sovereignty." Positively No Filipinos Allowed: Building Communities and Discourse, edited by Antonio T. Tiongson, Edgardo V. Gutierrez, and Ricardo V. Gutierrez. Temple UP, 2006, pp. 90-109.

Bhabha, Homi K. The Location of Culture. Routledge, 1994.

Denton, Kirk A. "The Distant Shore: Nationalism in Yu Dafu's "Sinking." Chinese Literature: Essays, Articles, Reviews (CLEAR), vol. 14, 1992, pp. 107-123.

Dirlik, Arif. "Chinese History and the Question of Orientalism." History and Theory, vol. 35, no. 4, 1996, pp. 96-118. JSTOR, www.jstor.org/stable/2505446. Accessed 22 Feb. 2017.

Fouron, Georges E. "Modern Diasporas in the Age of Globalization." International Studies Review, vol. 6, 2004, pp. 461-463.

Kwak, Hyoungduck. "Forgetting and Remembering Kim Saryang." 28th AKSE Conference Prague 2017 (AKSE 2017), 20-23 Apr. 2017, Hotel Pyramida, Prague, Czech Republic. Conference Paper. AKSE 2017 Agenda, www.conference-service.com/akse2017/ documents/agenda/data/abstracts/abstract_384.html. Accessed 22 Feb. 2017.

Parashkevova, Vassilena. Salman Rushdie's Cities: Reconfigurational Politics and the Contemporary Urban Imagination. Continuum, 2012. Google Books, https://books. google.com.ph/books?id=cnMSBwAAQBAJ\&pg=PA18\&lpg=PA18\&dq=postcolon ial + mimicry + , mirror\&source $=$ bl\&ots $=X g b 8 s A X s d e \& s i g=2 u o y 6 x d 2 z y \_r 7 d v 2 P_{2} E e$ 9t6TjgU\&hl=en\&sa $=X \&$ redir_esc $=y \# v=$ onepage $\& \mathrm{q}=$ postcolonial\%2omimicry\%2o $\% 2$ Cmirror\&f=false. Accessed 21 Feb. 2017. 